\title{
Phase I Archaeological Survey of a 10-acre Habitat for Humanity Tract in Laredo, Webb County, Texas
}

Bruce K. Moses

Russell D. Greaves

Charles S. Smith

Follow this and additional works at: https://scholarworks.sfasu.edu/ita

Part of the American Material Culture Commons, Archaeological Anthropology Commons, Environmental Studies Commons, Other American Studies Commons, Other Arts and Humanities Commons, Other History of Art, Architecture, and Archaeology Commons, and the United States History Commons

Tell us how this article helped you.

This Article is brought to you for free and open access by the Center for Regional Heritage Research at SFA ScholarWorks. It has been accepted for inclusion in Index of Texas Archaeology: Open Access Gray Literature from the Lone Star State by an authorized editor of SFA ScholarWorks. For more information, please contact cdsscholarworks@sfasu.edu. 


\section{Phase I Archaeological Survey of a 10-acre Habitat for Humanity Tract in Laredo, Webb County, Texas}

\section{Creative Commons License}

\section{(c) (i) (9)}

This work is licensed under a Creative Commons Attribution-NonCommercial 4.0 International License 


\title{
Phase I Archaeological Survey of a 10-acre Habitat for Humanity Tract in Laredo, Webb County, Texas
}

\author{
by \\ Bruce K. Moses, Russell D. Greaves and Charles S. Smith
}

Prepared for:

Habitat for Humanity of Laredo

1907 Freight Street

Laredo, Texas 78041

\section{Prepared by:}

Center for Archaeological Research The University of Texas at San Antonio Archaeological Survey Report, No. 355 


\title{
Phase I Archaeological Survey of a 10-acre Habitat for Humanity Tract in Laredo, Webb County, Texas
}

\author{
by \\ Bruce K. Moses, Russell D. Greaves and Charles S. Smith
}

Steve A. Tomka

Principal Investigator

Prepared for:

Habitat for Humanity of Laredo 1907 Freight Street Laredo, Texas 78041

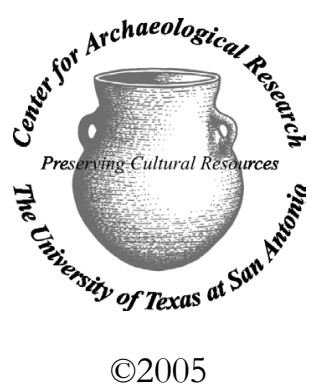

Prepared by:

Center for Archaeological Research The University of Texas at San Antonio Archaeological Survey Report, No. 355 


\section{Abstract:}

On December 7, 2004, the Center for Archaeological Research (CAR) conducted a Phase I intensive pedestrian archaeological survey of a 10-acre portion of Tract 4 in the Las Blancas Subdivision located near Laredo in Webb County, Texas, for Habitat for Humanity of Laredo. The proposed development consists of the construction of low-income housing within this parcel.

Twenty shovel tests were excavated along 20-meter transects and in areas considered to have high or moderate probability of buried cultural materials. In addition, two backhoe trenches were excavated in alluvial deposits along the eastern margin of the project area overlooking Blancas Creek. The survey resulted in the identification of one archaeological site, 41WB633, an apparent lithic procurement locality.

Site 41WB633 covers approximately 6.4 acres and extends beyond the survey area. The core area with the highest density of surface materials measures approximately $65 \times 45$ meters and contains early reduction stage bifaces, cores, and lithic debitage scattered across the surface. Only one of the 20 shovel tests (ST 10) placed within the site recovered subsurface materials buried in Levels 1-3, at $0-30 \mathrm{~cm}$ below surface. Neither of the two backhoe trenches excavated within the boundaries of the site yielded subsurface materials.

The geoarchaeological investigations indicate that the prehistoric lithic artifacts show no evidence of alluvial or colluvial abrasion and only minimal patination was observed on a few pieces. This suggests that they are not the product of significant high-energy redeposition. Although the surface gravels may have been formed by colluvial or eolian processes, the fresh, undamaged edges of the lithics indicate that events concentrating the gravels probably occurred prior to deposition of the archaeological materials.

Given the lack of isolable archaeological deposits at 41WB633, the overall low density of cultural materials, and the absence of a comprehensive research context within which such lithic procurement sites can be interpreted, CAR recommends that the site does not merit designation as a State Archeological Landmark and does not warrant nomination to the National Register of Historic Places. Therefore, it is CAR's recommendation that the construction work associated with the development of this 10 -acre portion of the Las Blancas Subdivision proceed as planned.

Because the property was privately owned at the time of the fieldwork, and no state funds will be employed in the construction effort, no Texas Antiquities Committee permit was necessary for this undertaking. The artifacts collected during the survey will be curated at CAR unless otherwise requested by the landowner. All project-associated documents are curated at the Center for Archaeological Research at The University of Texas at San Antonio. 


\section{Table of Contents:}

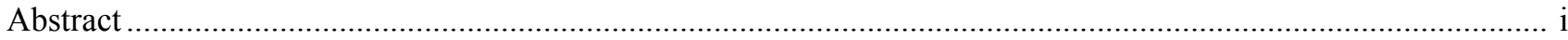

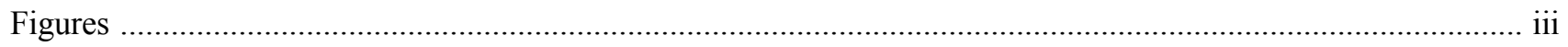

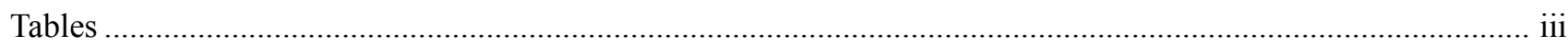

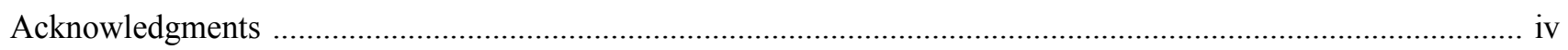

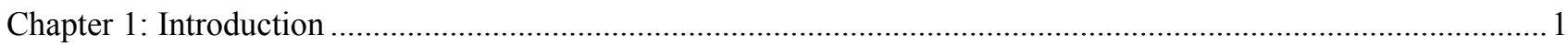

Chapter 2: The Project Area and Known Archaeological Sites in the Vicinity ....................................................... 4

Chapter 3: Archaeological Field and Laboratory Methods .............................................................................. 6

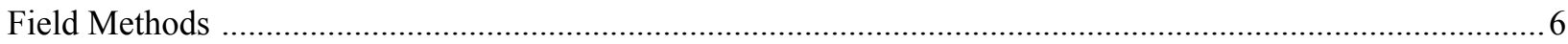

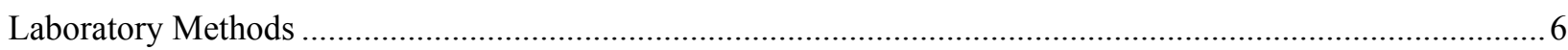

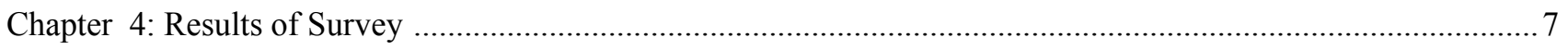

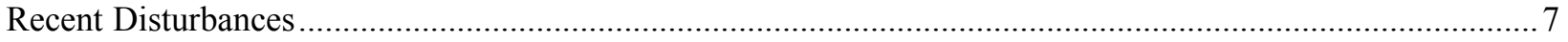

Results of the Pedestrian Survey and Shovel Testing ................................................................................ 10

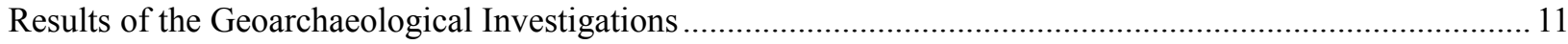

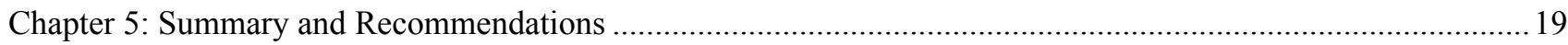

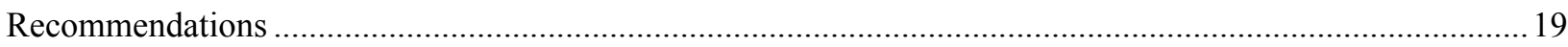

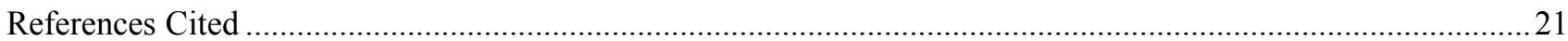




\section{Figures:}

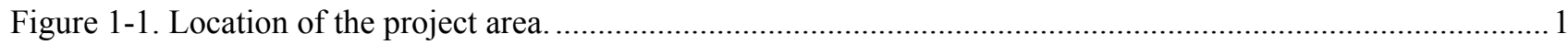

Figure 1-2. The project area on the Blancas Creek, Texas, USGS quadrangle map. ............................................2

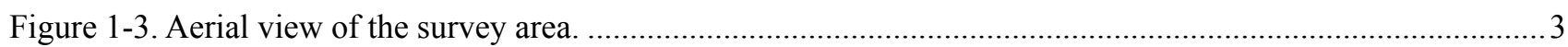

Figure 4-1. Site 41WB633, showing locations of shovel tests, backhoe trenches, and the artifact concentration...... 7

Figure 4-2. Borrow pit along the western margin of the project area. ................................................................ 8

Figure 4-3. Push pile and grass cover in the western portion of the project area................................................... 9

Figure 4-4. Vegetation cover common in the eastern half of the project area. ................................................... 9

Figure 4-5. Distal end of biface or projectile point found on the surface of Site 41WB633............................... 11

Figure 4-6. Biface (a) and cores (b-d) recovered from shovel tests on Site 41WB633 ........................................ 12

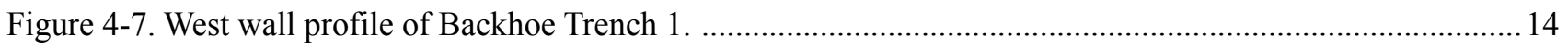

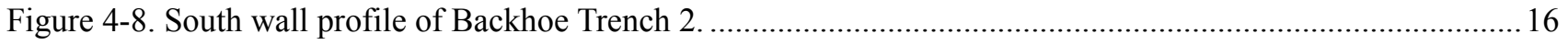

\section{Tables:}

Table 4-1. Terminal Depth of Shovel Tests Not Excavated to Target Depth of $60 \mathrm{cmbs}$....................................... 10

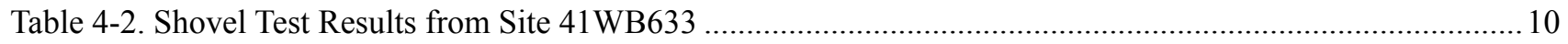

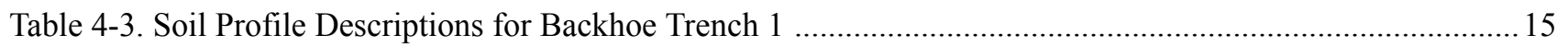

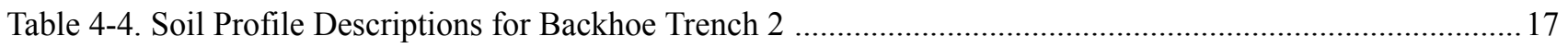




\section{Acknowledgments:}

Although this project represented only a one-day survey of a small property, several people have been very helpful with the logistical preparations, the actual survey, the production of the draft report, review, and the final publication. We would like to express our thanks to Carol S. Sherwood, Executive Director of Habitat for Humanity of Laredo, for facilitating contractual aspects of the project, Viky Garcia, Special Projects Director, for helping lay the groundwork for the project, setting up the backhoe and operator, and meeting the crew at the project location. We would also like to thank Mr. Hector Rubio of Laredo for providing the backhoe and for his skillful operation. The authors would also like to thank Dr. Steve A. Tomka, CAR Director, for reviewing a draft of this report. Clearly, thanks are also due to the field crew composed of Brian DavisBrothers, Jon Dowling, Maggie Moore, and Steve Smith for their hard work. Richard Young and Bruce Moses drafted the figures and Johanna Hunziker formatted the final report. 


\section{Chapter 1: Introduction}

In November 2004, Habitat for Humanity of Laredo, Webb County, contracted with the Center for Archaeological Research (CAR) of The University of Texas at San Antonio to conduct a Phase I intensive pedestrian survey of an approximately 10 -acre $(4.05$-hectare) property located in extreme eastern Laredo, Webb County, Texas (Figure 1-1). The property, located on Tract 4 of the Las Blancas Subdivision on the north side of Highway 359, is to be used for the construction of 45-50 low-income housing units.
The 10-acre parcel was privately owned at the time of the survey, although the housing unit will receive Department of Housing and Urban Development (HUD) funds to complete the project. Section 106 of the National Historic Preservation Act (NHPA) requires federal agencies to take into consideration the effects of proposed undertakings on cultural resources within the Area of Potential Effect (APE). While the proposed undertaking is on privately owned property and not funded by State funds, the use of HUD

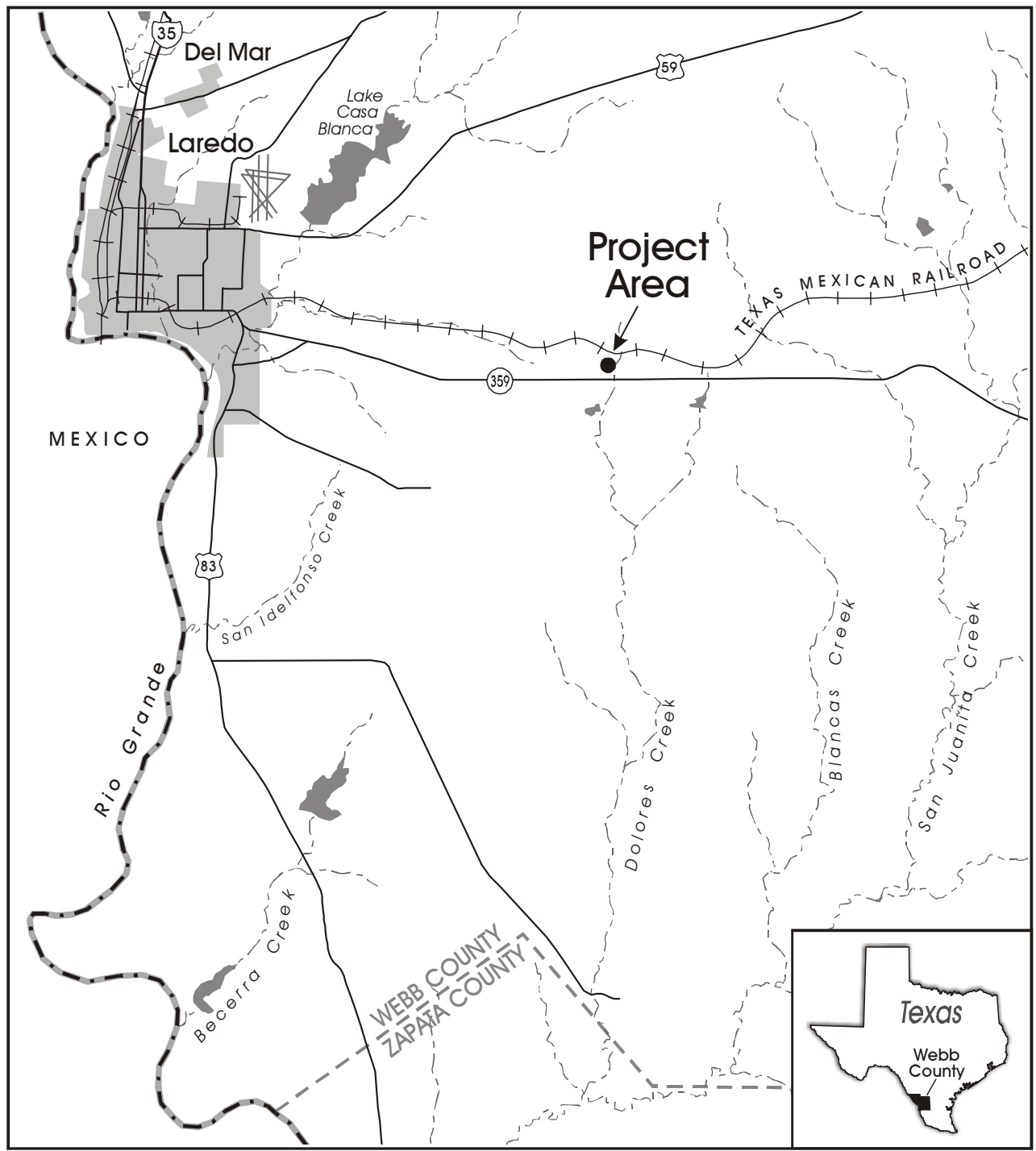

Figure 1-1. Location of the project area. 
Phase I Survey of a Habitat for Humanity Tract in Laredo

funds makes this project a federal undertaking as defined under 36 CFR part 800.16(y). As such, it falls under Section 106 of the NHPA.

In these circumstances, no state Antiquities Permit is needed for the undertaking but the Department of Antiquities Protection of the Texas Historical Commission serves as the reviewing agency.

Figure 1-2 shows the project area on the 1993 edition of the Blancas Creek Texas 7.5' USGS quadrangle map. An aerial view of the project area is shown in Figure 1-3.

Tract 4 is located immediately adjacent to and north of Highway 359 in east Laredo. It abuts Tract 3 to the west and Tract 5 to the east. Its northern limits extend to the Texas Mexican Railroad running east and connecting Laredo to Hebbronville. The actual 10 -acre portion of the tract that was the subject of the survey is an L-shaped property in roughly the center of Tract 4 (Figure 1-2).

The survey area sits at an elevation of 560-600 feet (171$183 \mathrm{~m}$ ) above mean sea level (AMSL) approximately 400 meters west of Dolores Creek. The creek crosses the southeastern corner of Tract 4 but it does not enter the 10acre survey tract. The terrain within the project area slopes gently to the south-southeast toward Dolores Creek.

Due to primary and secondary development impacts associated with access roads, sidewalks, driveways, and house construction, the entire 10 acres is considered the APE. At the time of the survey, the types and locations of specific impacts had not been determined. Similarly, the maximum depth of construction impacts across the survey area had not been set nor restricted by the owner of the property.

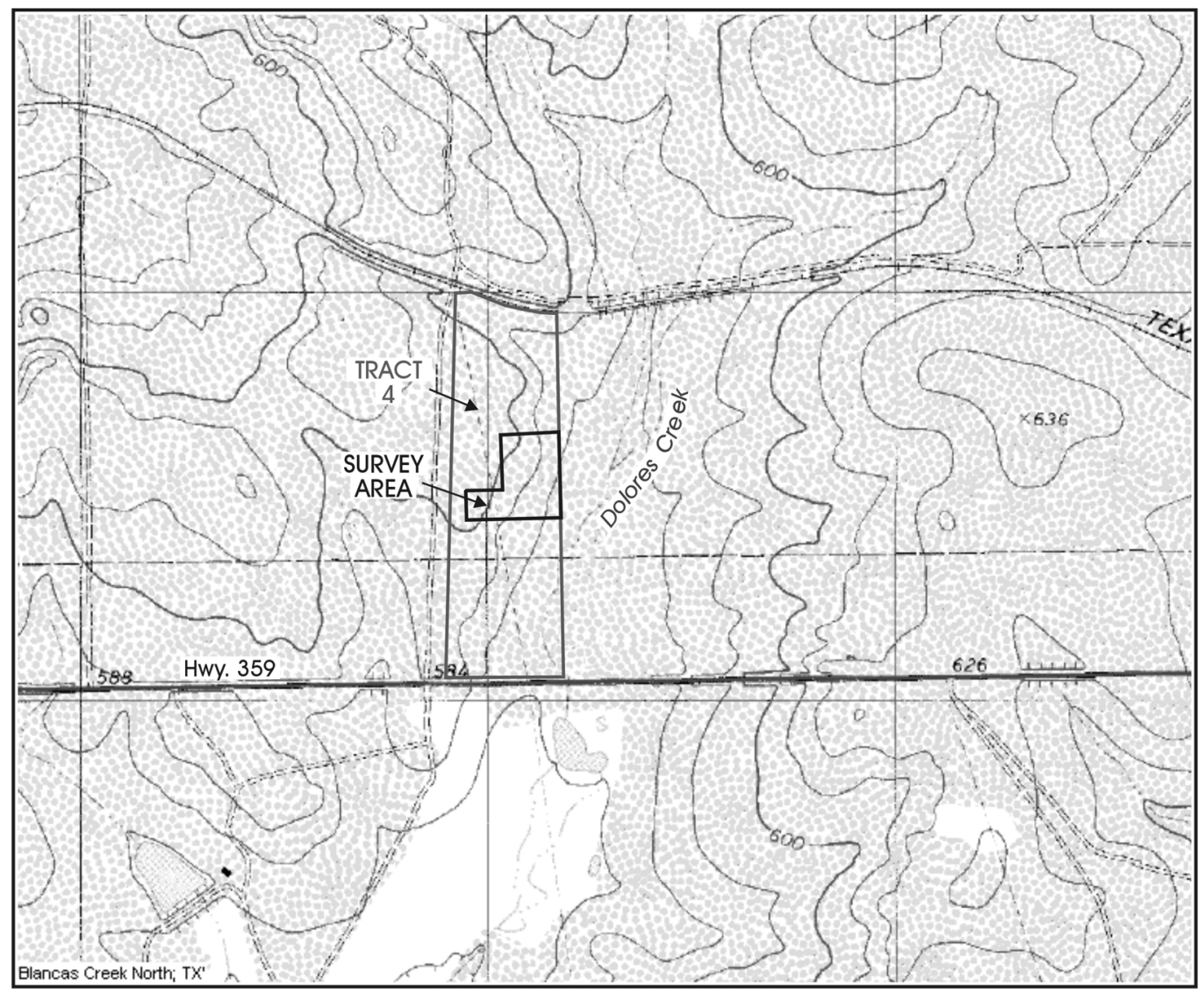

Figure 1-2. The project area on the Blancas Creek, Texas, USGS quadrangle map. 


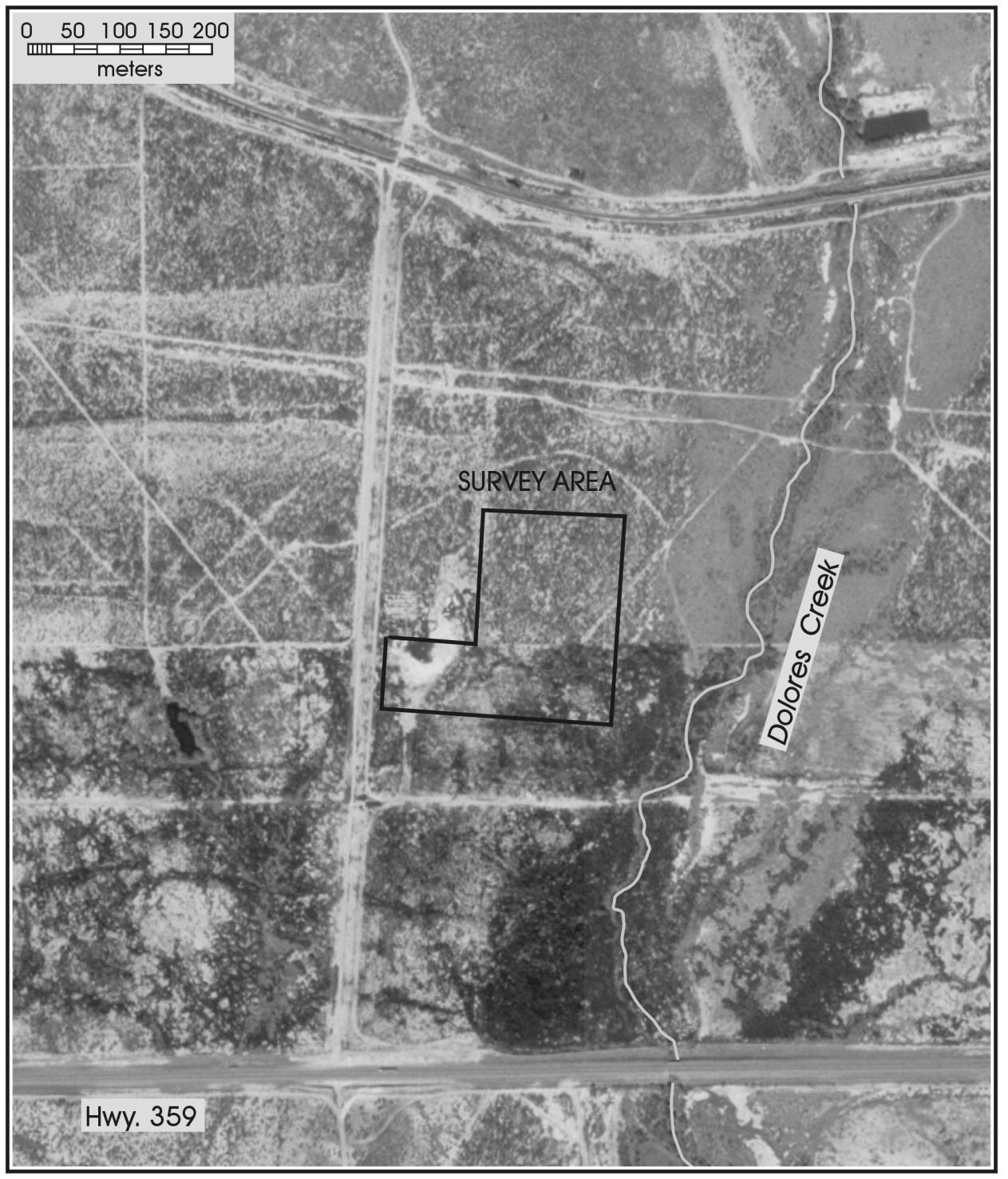

Figure 1-3. Aerial view of the survey area. 


\section{Chapter 2: The Project Area and Known Archaeological Properties in the Vicinity}

The Laredo area is located near the approximate boundaries of the Chihuahuan, Balconian, and Tamaulipan biotic provinces (Blair 1950:Figure 1). Although technically within the boundaries of the northwestern Tamaulipan biotic province (Blair 1950:102-105), this area also may usefully be characterized by reference to Chihuahuan Desert vegetation dynamics. Controversy over Chihuahuan vegetation boundaries and recent alterations in plant distributions (Blair 1950:102; Brown 1994:169) suggest that strict assignment may be problematic. This area is characterized as part of the South Texas brush country. It especially resembles Chihuahuan creosote bush-dominated thorn brush vegetation (Blair 1950:106-107). Less disturbed portions of these older, higher terraces are characterized by desert scrub vegetation dominated by creosote bush (Larrea tridentata), mesquite (Prosopis spp.), thorn brush, paloverde (Cercidium texana), salt bush (Atriplex spp.), prickly pear cactus (Opuntia spp.), other cacti (Ancistrocactus spp., Echinocactus spp., Echinocereus spp., Mammillaria spp.), and many leaf and stem succulents (Agave spp., Dasylirion spp., Yucca spp.). The cactus diversity in the Texas portion of the Chihuahuan Desert is extensive (Brown 1994:177). Grass species (primarily Cenchrus ciliaris, Cynodon dactylon, and Sorghum halepense) have been encouraged through natural and human initiated fires. Hackberry (Celtis laevigata) and willow (Salix nigra) are present on some lower terrace settings. Recent blading to remove large shrubs and trees has maintained the project area in a subclimax colonization vegetation dominated by mixed thorn brush, creosote bush, and cactus.

The project area ranges in elevation from $184 \mathrm{~m}$ AMSL at its highest point in the northwest to $177 \mathrm{~m}$ AMSL sloping toward Dolores Creek just a little more than $85 \mathrm{~m}$ to the southeast. Initially, the project area was identified as consisting of all of Tract 4; therefore, it was estimated that at least its extreme southeastern portion would fall within the floodplain of Dolores Creek. Subsequent information placed the 10-acre tract roughly in the center of Tract 4 well west of and overlooking the floodplain of the creek. No other creeks are found in the vicinity of the project area.

The project area consists of deep clay soils overlying Laredo Formation Eocene sandstones (Groat 1976) and is situated where the Maverick-Catarina complex soils are mapped (Sanders and Gabriel 1985:30-31, 80, Sheet 84). The setting indicates that Catarina soils are probably represented in the area investigated (Sanders and Gabriel 1985:21, 73-74). Viboras series soils are identified along the margin of the upper terrace investigated during the project (Sanders and Gabriel 1985:37-38, 86-87). The surface soils of this are identified as primarily clayey soils with few siliceous gravels that overlie B horizons with significant amounts of calcium and other salts. Lithic raw materials in the form of wellrounded chert cobbles are common on the surface across the entire site.

Paleoclimatic reconstructions for this area rely heavily on trends recorded for Central Texas (Bousman 1998) that are applicable to South Texas (Black 1989; Hester 1995; Vierra 1998:Figure 2-2). In general, mesic conditions predominated during the Late Pleistocene and Early Holocene $(12,000$ 8000 BP). The Middle Holocene (8000-4500 BP) is characterized as more xeric. The fluctuations from 6000 $5000 \mathrm{BP}$ represent an apparent increase in moisture followed by dramatic evidence of drying events identified as the Altithermal. Subsequent to the Altithermal, more mesic conditions occurred and continue into the present (Holloway 1986). These trends are certainly germane, however, their local expression within any particular archaeological site is problematic. Nordt's (1998:71-77) detailed reconstruction from site 41MV120, north of Eagle Pass on Elm Creek, indicates the importance of very local climatic responses.

The prehistoric chronology of Webb County, and South Texas in general, is poorly known (Hester 1995). Few deeply stratified and undisturbed archaeological sites have been excavated in the region and it is likely that few geomorphological settings are present where these sites can be found. Based on the temporally diagnostic artifacts recovered, human presence in the region extends back to the Paleoindian period (12,000-8000 BP) and continues through the Toyah Phase of the Late Prehistoric period (650-300 BP; Hester 1995). Cultural materials from temporally distinct periods are usually found on the surface, sometimes in spatially distinct clusters but often mixed within the same concentration (Hester 1995).

A review of the Texas Archeological Sites Atlas (Texas Historical Commission [THC] 2004) indicates that there is one previously recorded archaeological site located within Tract 4. Although this site, 41WB442, is not within the 
project area proper, it is within the right-of-way (ROW) of Highway 359 and was recorded by M. Quigg of Mariah Associates, Inc. in 1997. At the time of its recording, it was estimated that the limits of the site extended to the north outside of the highway ROW into Tract 4. However, no work was conducted outside of the ROW proper. The site was identified as a temporary campsite but no temporal affiliation could be approximated given the lack of temporally diagnostic artifacts on site. Cultural materials were documented to a depth of at least $40 \mathrm{~cm}$ below surface. Shovel testing revealed intact deposits. Burned chert and sandstone and chert flakes were recovered in the shovel tests and early stage bifaces and cores were present on surface. 


\section{Chapter 3: Archaeological Field and Laboratory Methods}

To carry out the cultural resources inventory of the project area, CAR was to conduct a 100 percent intensive pedestrian archaeological survey of the proposed project area accompanied by subsurface testing. Both archaeological and standing structural resources were to be considered using visual inspection of the surface and subsurface shovel testing and backhoe trenching as determined appropriate by the project archaeologist.

\section{Field Methods}

Given the 10-acre size of the project area, 20 shovel tests (STs) were excavated as part of the original scope of work submitted with the permit application and as per the Minimum Survey Standards of the Texas Historical Commission. As part of the pedestrian survey, archaeologists traversed the APE in 30-m transects while placing shovel tests evenly across the tract and/or in areas of high probability for recovering archaeological materials as judged appropriate by the project archaeologist. All shovel tests were manually excavated to $60 \mathrm{~cm}$ below surface $(\mathrm{cmbs})$ unless otherwise prohibited from reaching that depth. Each test was excavated in $10-\mathrm{cm}$ levels and measured $30 \mathrm{~cm}$ in diameter. Matrix from each level was screened through 1/4-inch mesh. Shovel test forms were completed, in pencil, for each test noting observations about the soils, artifacts, and any other pertinent information relevant to the survey. All shovel test locations were recorded using a Trimble GeoExplorer II Global Positioning System (GPS) unit and sketched onto aerial photographs and the topographic quadrangle map. All artifacts recovered from shovel tests were bagged by provenience and returned to the CAR laboratory for processing, analysis, and curation.

Isolated artifacts, referred to as "isolated finds," consisting of individual artifacts separated by at least 30 meters from their nearest neighbor, also were mapped with a GPS unit. Only those artifacts exhibiting characteristics diagnostic of specific cultural groups or time periods were collected. All other surface artifacts observed in the field were described in the field notes and left in place.

Because it was thought that the survey parcel consisted of all of Tract 4, originally three backhoe trenches (BHTs) were to be excavated to inspect subsurface deposits for cultural materials. When it was learned the actual survey area did not include the modern or recent floodplain surfaces, only two backhoe trenches were excavated on an abandoned terrace of Dolores Creek. All trench excavations were monitored during excavation. Each trench was approximately $1 \mathrm{~m}$ wide and was excavated to approximately $1.5-$ $2.0 \mathrm{~m}$ below surface. Both walls of each backhoe trench were examined for evidence of any potential archaeological artifacts, features, or significant indicators of formation events. However, only one representative wall segment of each exposure was systematically trowelled for profiling and drawn. Full soil descriptions were performed on one profile within each of the trenches. Complete field soil observations included soil texture, consistence (wet and dry), presence and morphology of clay films, grain coatings, structure, abundance and size of roots, abundance and size of pores, presence of calcium carbonate, horizon boundaries, and Munsell colors (wet and dry). These attributes permit designation of the soil and sedimentary horizons in standard soil nomenclature (Birkeland 1984:353-360; Soil Survey Staff 1993:117-135).

\section{Laboratory Methods}

Artifacts recovered during the survey were washed, air-dried, and stored in 4-mil zip-locking bags at the CAR laboratory. Acid-free labels were placed in all artifact bags. Each label included provenience information and a corresponding lot number written in archival ink or pencil, or laser printer generated. Tools and ceramics were labeled with permanent ink over a clear coat of acrylic and covered by a second acrylic coat. In addition, a small sample of unmodified debitage from each lot was labeled with the appropriate provenience data. Artifacts were separated by class and stored in acid-free boxes identified with standard tags.

All project-related field notes, forms, photographs, and drawings were placed in labeled archival folders. Photographs, slides, and negatives were labeled with archivally appropriate materials and placed in archival-quality sleeves. Any soiled shovel test forms were placed in archival-quality page protectors. Ink-jet produced maps, illustrations, etc. also were placed in archival-quality page protectors to provide against accidental smearing due to moisture. 


\section{Chapter 4: Results of Fieldwork}

\section{Recent Disturbances}

The western margin of the 10 -acre tract surveyed by the CAR crew included large areas heavily impacted by gravel mining excavations and possible vegetation clearing (Figure 4-1). The mining activities apparently focused on the removal of caliche or gravel deposits, and resulted in the removal and/or redistribution of surface materials across much of the western portion of the surveyed tract. This heavily impacted portion of the property, consisting of approximately 3.7 acres, includes several borrow pits (less than $4 \mathrm{~m}$ deep; Figure 4-2) and numerous push-piles of

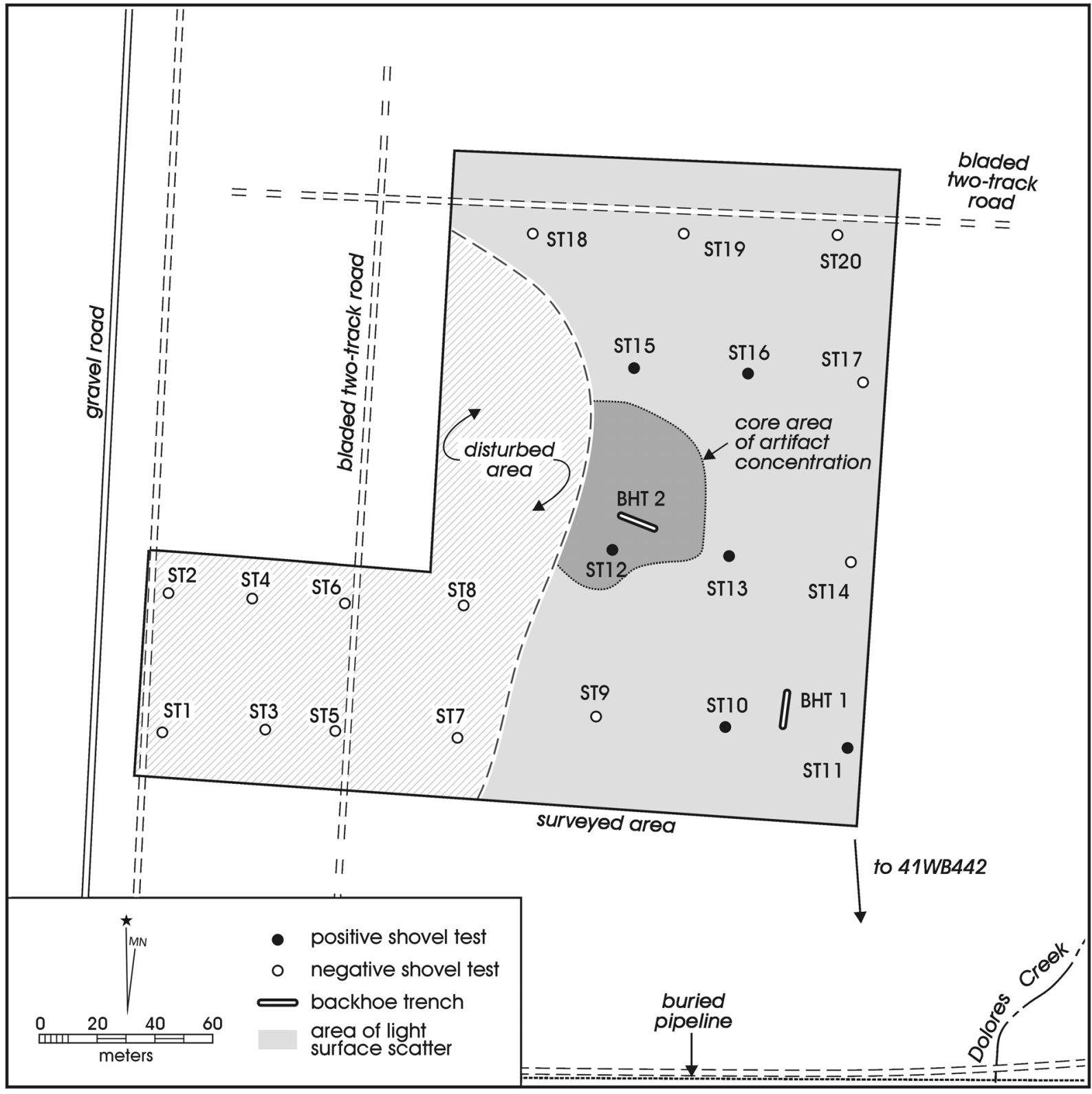

Figure 4-1. Site 41WB633, showing locations of shovel tests, backhoe trenches, and the surface artifact concentration. 


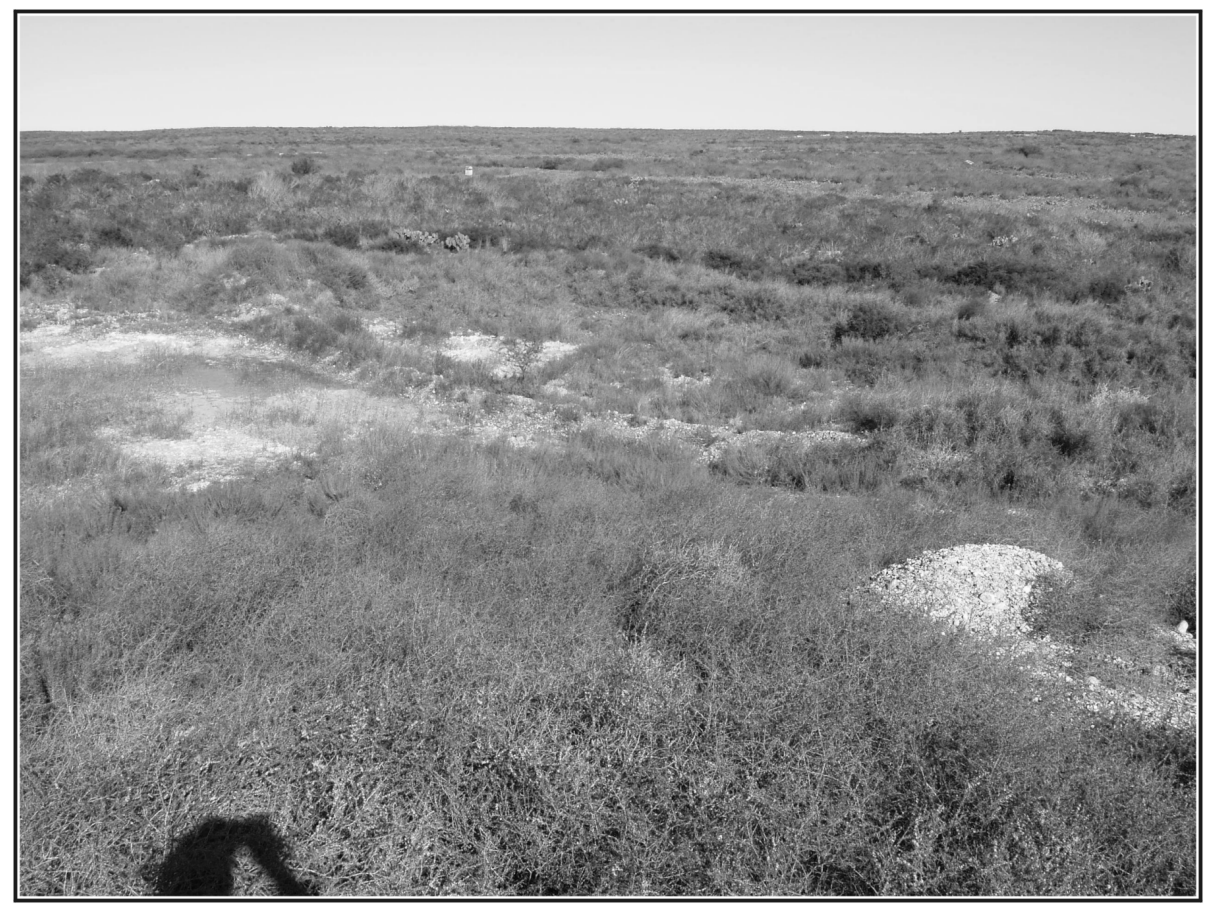

Figure 4-2. Borrow pit along the western margin of the project area.

sediment and gravels (Figure 4-3). Many of these impacts appear to be very recent as evidenced by the size of the effected area in a digital orthophoto quad taken of the area in January 1995 (Figure 1-3). At that time, the area of mining activities on the surveyed tract appear to have been restricted to approximately two acres of the total 10 -acre project area. During the pedestrian survey, this disturbed area was observed to extend to the north, west, and south of the surveyed tract.

Brush clearing and subsequent burning also appears to have occurred within the area over the past several years. Multiple burn piles composed of pushed-up sediment, gravels, firecracked rock, charcoal and ash were observed in the southeast quadrant of the property. This area, which accounts for approximately 20 percent of the total surveyed tract, showed a distinctive change in vegetation from that shown in the aerial photograph. Overall, these gravel-mining activities combined with land clearing have created a vegetation community dominated by lush grasses across much of the western portion of the APE. The grass cover reduced surface visibility to zero across much of the area, although patches of bare ground were visible within the sea of grass.

In contrast, the vegetation cover throughout the eastern portion of the project area consists of a combination of tall grasses, clumps of prickly pear, and agarita (Figure 4-4). Open patches completely devoid of vegetation are also common across this area. In these areas, the ground is covered with a blanket of gravels, many of them consisting of good-quality cherts that would have made excellent raw materials for prehistoric flintknappers.

Finally, several two-track roads bladed across the property postdate the 1995 aerial photograph, including one northsouth road that bisects the disturbed western portion of the property and another that forms the western boundary of the 10-acre tract. The extreme northern portion of the project area is crossed by an east-west running two-track road while an older, overgrown east-west running two-track road was noted during the survey approximately 90 meters north of the southern boundary of the project area. 


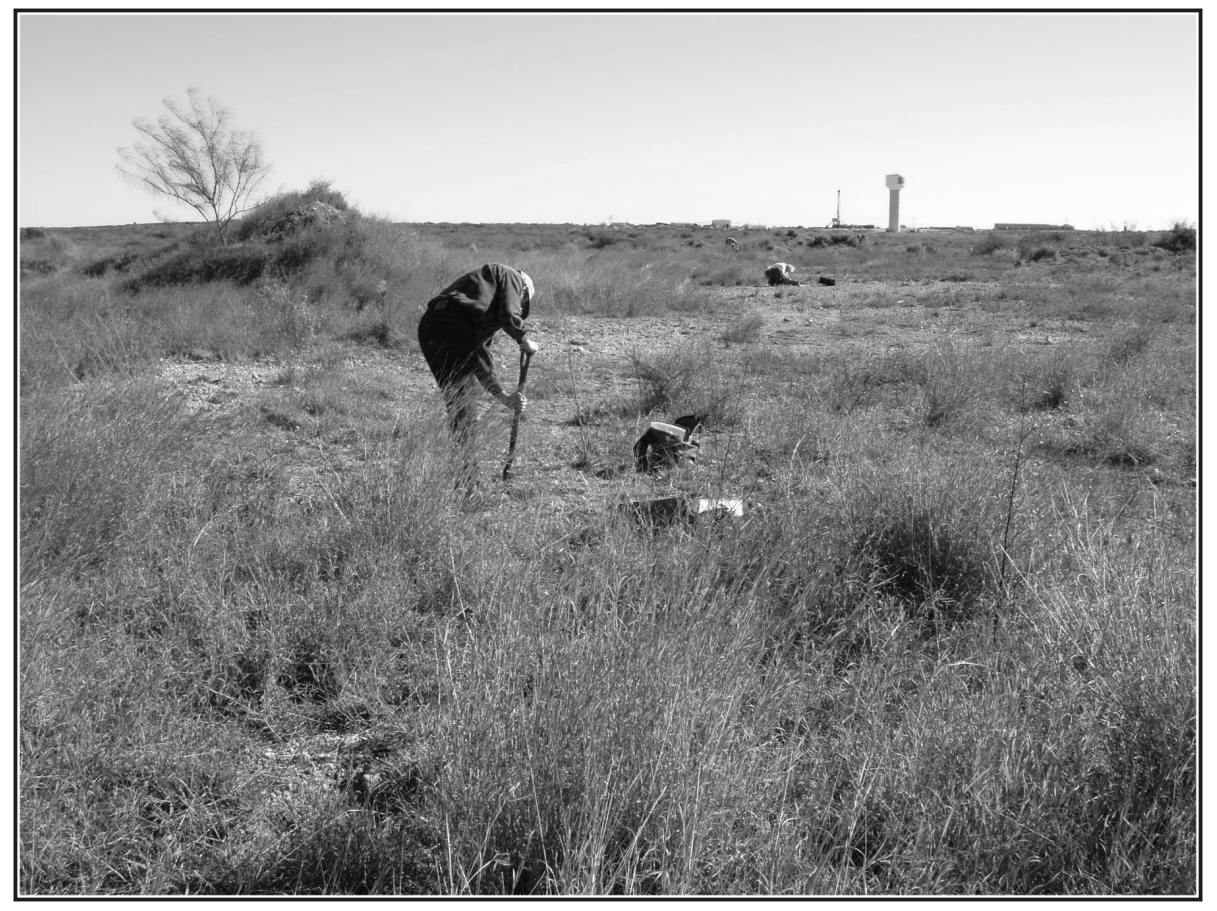

Figure 4-3. Push-pile and grass cover in the western portion of the project area.

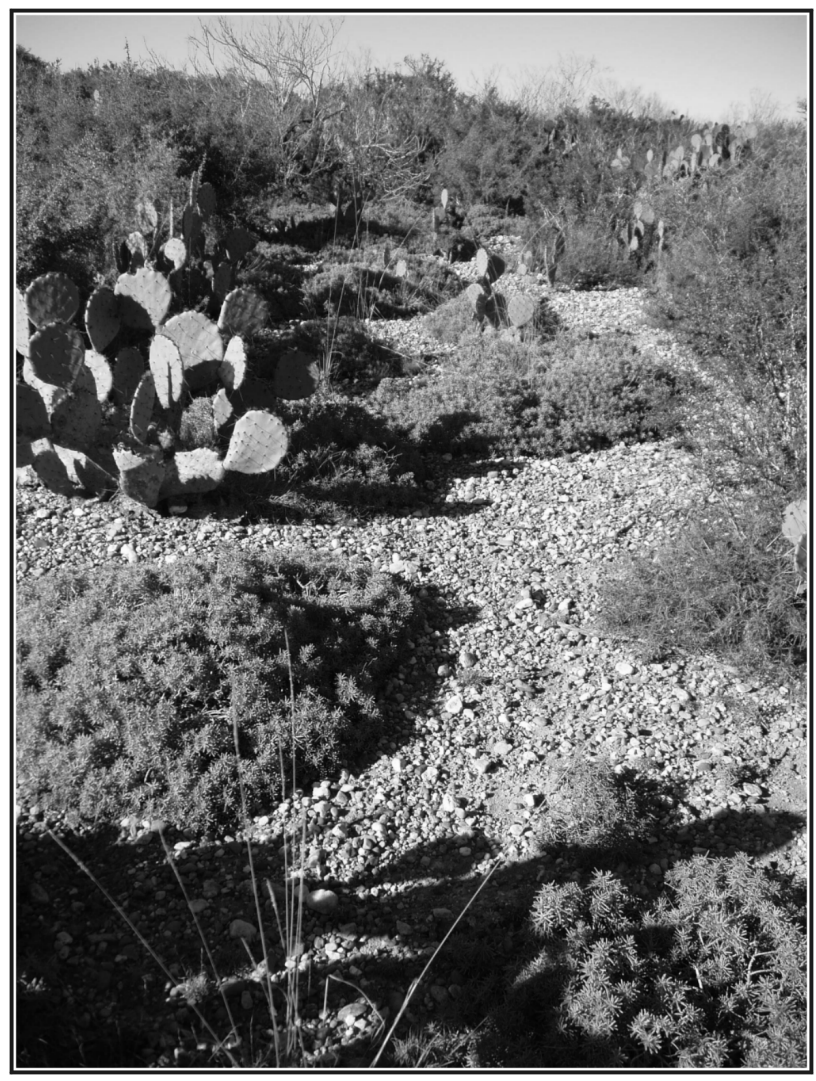

Figure 4-4. Vegetation cover common in the eastern half of the project area. 


\section{Results of the Pedestrian Survey and Shovel Testing}

The pedestrian survey identified a surface concentration of archaeological materials consisting of flakes, tested cobbles, cores and early stage bifaces in the central portion of the property. This central area, occupying just over one-half of an acre, transitioned into a relatively light but extensive surface scatter that covered the remainder of the surveyed tract east of the heavily modified and cleared area. No cultural materials were observed on the surface within the disturbed western portion of the surveyed tract.

Twenty shovel tests (STs 1-20) and two backhoe trenches (BHTs 1-2) were excavated within the project area. Shovel Tests $1,2,6$, and 18 were terminated before reaching the target depth of $60 \mathrm{cmbs}$ (Table 4-1). All others were excavated to the base of Level $6(60 \mathrm{cmbs})$. The shallower shovel tests were terminated when the excavators reached dense gravels that they perceived as sterile basal gravels. It was later found that all other shovel tests encountered these gravels but the excavators continued through them to the target depth before stopping. Six (30\%) of the shovel tests (STs 10, 11, 12, 13, 15, and 16) were positive for cultural materials but an inspection of the provenience of the artifacts indicates that in five of these, the materials were encountered on the surface prior to the inception of excavation (Table 4-2).

Shovel Tests 1-8 were placed in the westernmost portion of the 10 -acre parcel to test for possible buried cultural materials as well as to investigate the depth of previous disturbances (Figure 4-1). These shovel tests were all sterile and the uppermost natural sediments and gravels had been removed and/or otherwise disturbed.

The surface around Shovel Tests 1 and 2 was clearly disturbed as a result of the adjacent two-track road. Levels 1 through 5 consisted of compact silt/sand with pebbles and gravels. Shovel Test 1 was terminated at Level 5, approximately $50 \mathrm{~cm}$ below surface, and Shovel Test 2 was terminated at approximately $32 \mathrm{~cm}$ below surface due to impenetrable sterile gravels. Shovel Tests 3-5 were excavated to $60 \mathrm{cmbs}$ in an area that was evidently highly disturbed. Level 1 in these shovel tests typically consisted of hard-packed silt/sand with gravel that was light tan in

Table 4-1. Terminal Depth of Shovel Tests Not Excavated to Target Depth of $60 \mathrm{cmbs}$

\begin{tabular}{|c|c|}
\hline Shovel Test No. & Terminal Depth \\
\hline 1 & $50 \mathrm{cmbs}$ \\
\hline 2 & approx. $32 \mathrm{cmbs}$ \\
\hline 6 & $30 \mathrm{cmbs}$ \\
\hline 18 & $24 \mathrm{cmbs}$ \\
\hline
\end{tabular}

Table 4-2. Shovel Test Results from 41WB633

\begin{tabular}{|c|l|c|c|}
\hline Shovel Test No. & \multicolumn{1}{|c|}{ Artifact } & Count & Level of Artifact (cmbs) \\
\hline 11 & Debitage & 2 & Surface \\
\hline 12 & Debitage & 1 & Surface \\
\hline 12 & Core & 1 & Surface \\
\hline 13 & Debitage & 1 & Surface \\
\hline 13 & Biface & 1 & Surface \\
\hline 15 & Debitage & 1 & Surface \\
\hline 16 & Core & 1 & Surface \\
\hline 10 & Debitage & 2 & $1(0-10)$ \\
\hline 10 & Core & 1 & $2(10-20)$ \\
\hline 10 & Debitage & 1 & $3(20-30)$ \\
\hline
\end{tabular}


color. Levels 2 through 6 consisted of more compact silts/ sands interspersed with layers of gravels. Clay was also occasionally encountered below $50 \mathrm{~cm}$ in depth. Shovel Test 6 was ended at $30 \mathrm{~cm}$ below surface due to an impenetrable sterile layer of gravel. Shovel Tests 7 and 8 were placed near the eastern margin of the disturbed area at a location that appeared to have the greatest amount of natural soils removed. This highly disturbed area was also near a very large $(\sim 6 \mathrm{~m})$ gravel/caliche pile and previous bulldozer activity was visible near these shovel tests. The sediment consisted of compact clay/sand interspersed with pebbles and gravels throughout all levels.

\section{Site $41 \mathrm{WB} 633$}

Site 41WB633 was identified as an extensive lithic scatter occupying all of the survey area not modified by recent surface disturbances. This site area measures approximately 6.36 acres. The sparse surface scatter of cultural materials extends up to and beyond the survey area boundaries to the north, east, and southeast. Furthermore, because cultural material was observed to the very edge of the low berm that forms an eastern boundary for the heavily modified western portions of the surveyed tract, it is thought that the site likely once extended into this area before the recent excavations obliterated it. The pedestrian survey revealed that an area measuring approximately $65 \mathrm{~m}$ north-south by $45 \mathrm{~m}$ eastwest in the center of the 10-acre tract has the highest density of materials on site. Surface artifacts appear to diminish in frequency toward the northern boundary of the tract with the majority of the surface finds located along the eastern and southern portions of the site. Artifacts noted on surface include several multi- and uni-directional cores, early reduction stage bifaces, and lithic debitage. A well-made, and possibly use-broken, dart point fragment was also noted on surface (Figure 4-5). This find may indicate that perhaps activities other than lithic raw material procurement may have taken place on the landform.

Six of the 12 shovel tests placed across 41WB633 were positive. Of these, however, five contained only materials collected from the surface. Only ST 10 in the southeast portion of the project area contained subsurface cultural materials. The cultural materials recovered from the site consist of corticate debitage $(\mathrm{n}=8)$, cores and core fragments $(n=3)$ and an early reduction stage biface (Figure 4-6).

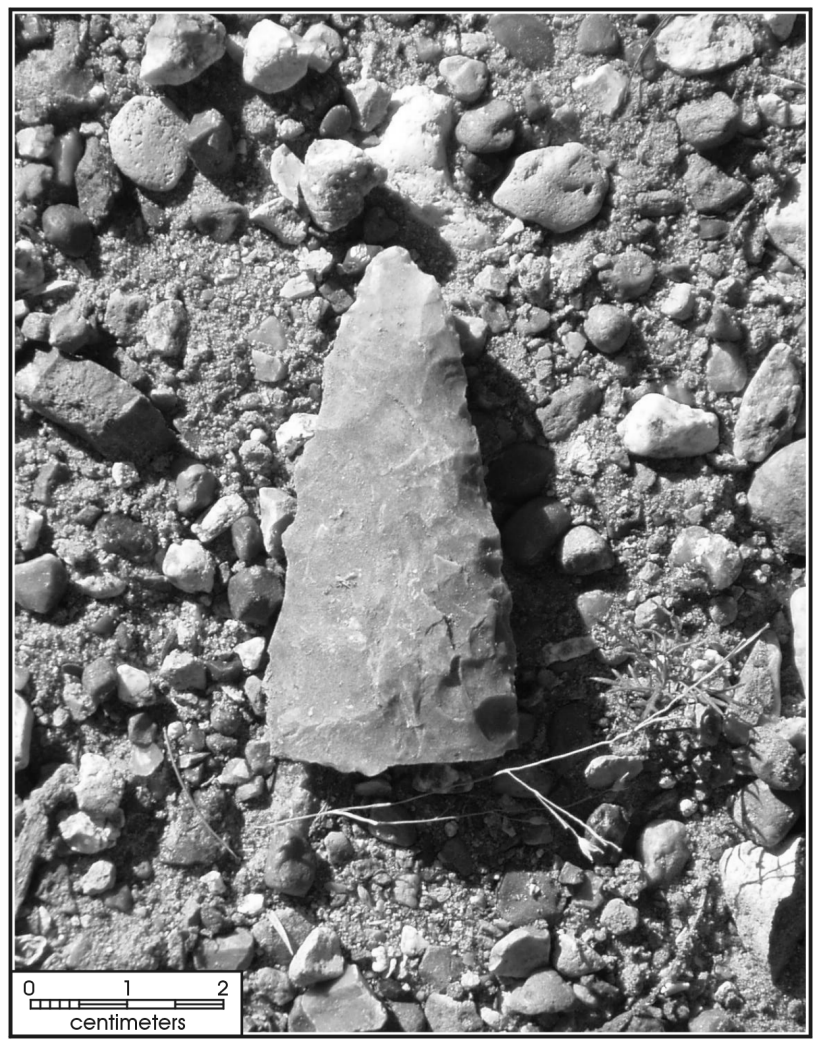

Figure 4-5. Distal end of biface or projectile point found on the surface of $41 \mathrm{WB} 633$.

\section{Results of the Geoarchaeological Investigations}

The project area is located on the western side of Dolores Creek, a first order tributary of the Rio Grande. The locality is situated at an elevation of 560-600 feet AMSL and is part of the eastern drainage area for the Rio Grande (Figure 1-1). Examinations focused on an abandoned terrace of Dolores Creek at the margin of uplands that extend northeast and southwest of the 10-acre tract where archaeological survey and geoarchaeological investigations were performed. Two backhoe trenches were excavated within the project area to determine subsurface potential for archaeological deposits and to describe landscape formation. Initially, excavation of mechanical trenches was designed to examine floodplain deposits of Dolores Creek. When fieldwork was 


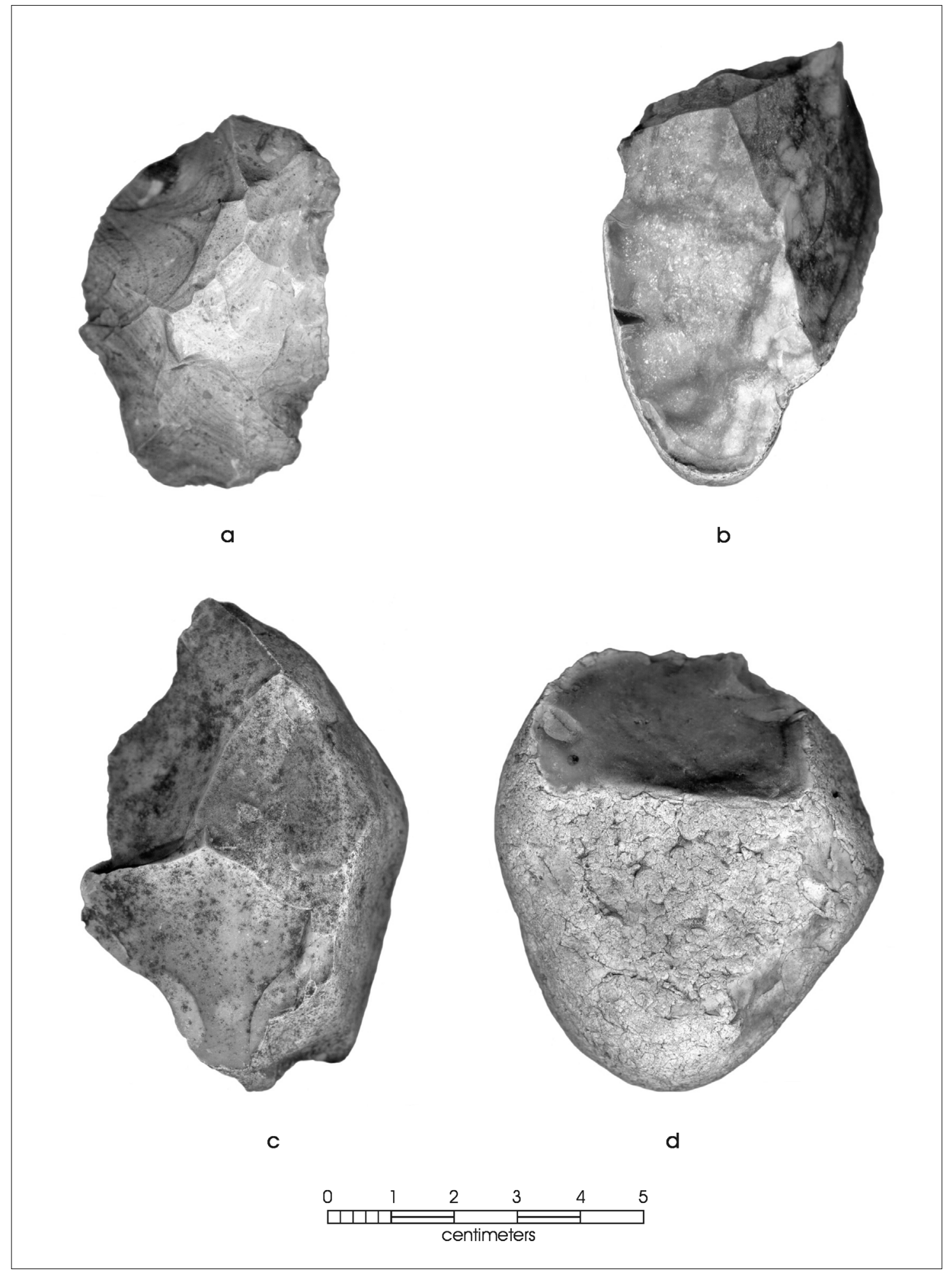

Figure 4-6. Biface (a) and cores (b-d) recovered from shovel tests on $41 \mathrm{WB} 633$. 
Phase I Survey of a Habitat for Humanity Tract in Laredo

initiated, further clarification of the APE indicated that none of the property was within modern or recent floodplain surfaces. The two trenches were used to examine terrace soils and geomorphology in areas where surface artifacts were identified and mechanical disturbances were minimal.

Two backhoe trenches were excavated in the high-energy alluvial deposits of an abandoned terrace of Dolores Creek (Figure 4-1). All trench excavation was monitored by the geoarchaeologist. Each trench was approximately $1 \mathrm{~m}$ wide and was excavated to approximately $1.5-2.0 \mathrm{~m}$ below surface. One trench (BHT 1) was excavated parallel (northsouth) to the channel of Dolores Creek to maximize areal exposure of any potential archaeological deposits on this terrace. Because the project area represents an older, broad abandoned terrace, trenching perpendicular to the creek was considered an unnecessary strategy for temporal sampling. BHT 2 was oriented perpendicular to the modern channel of Dolores Creek, but was situated to sample an area of the densest surface artifact distribution identified at the site and not provide a catina of contrasting terrace settings or investigate time-transgressive deposits. Both walls of each backhoe trench were examined for evidence of any potential archaeological artifacts, features, or significant indicators of formation events. However, only one wall of each exposure was systematically trowelled for profiling. Trowelling did not involve full cleaning of the entire exposure. Segments approximately $30 \mathrm{~cm}$ wide were carefully trowelled at $2-\mathrm{m}$ intervals. Some additional cleaning was necessary between these intervals to clarify horizon relationships. One wall of each backhoe trench was profiled and drawn. Full soil descriptions were performed on both trenches. Complete field soil observations included soil texture, consistence (wet and dry), presence and morphology of clay films, grain coatings, structure, abundance and size of roots, abundance and size of pores, presence of calcium carbonate, horizon boundaries, and Munsell colors (wet and dry). These attributes permit designation of the soil and sedimentary horizons in standard soil nomenclature (Birkeland 1984:353-360; Soil Survey Staff 1993:117135). Soils were examined for the presence of potentially datable charcoal but no such charcoal was identified.

\section{Backhoe Trench 1}

Backhoe Trench 1 was situated in the southeastern portion of the project area (Figure 4-1). It was placed to sample the area of this terrace within the project area that is nearest to the current channel of Dolores Creek. BHT 1 was situated approximately $100 \mathrm{~m}$ west of the active channel of Dolores Creek and was positioned to be nearest the plotted location of 41WB442 along the margin of Highway 359. Initial pedestrian reconnaissance of the project area identified a low density of large flakes, cores, and early stage bifaces in the vicinity of this trench. In the immediate vicinity there was evidence of mechanical scraping that was probably associated with removal of vegetation. No push-piles were located in the immediate vicinity of BHT 1 , however, there was nearby disturbance of surface deposits. No archaeological material or charcoal was observed in any portion of either profile wall of this trench.

BHT 1 was $12.76 \mathrm{~m}$ long and maximally $2.2 \mathrm{~m}$ deep. The trench was oriented $174^{\circ}-354^{\circ}$ from magnetic north. The west wall of BHT 1 was profiled (Figure 4-7) and described (Table 4-3). The profile contained a thin set of recent A horizons overlying gravel deposits that rested unconformably on older soils. The A horizons (A1-A3) were approximately $25 \mathrm{~cm}$ in maximum thickness. Only the A1 was present in the southern $4.1 \mathrm{~m}$ of this profile and it was less than $5 \mathrm{~cm}$ thick. Although surface artifacts were common, no archaeological materials were observed in the A horizons of either profile wall of this trench. The A horizons were fine, well-sorted silt loams with few clasts, all less than $2 \mathrm{~cm}$. The ground surface exhibited a moderate presence of larger alluvial gravels $(<10 \mathrm{~cm})$ and lithic artifacts made on these local materials. The surface gravels may represent lag deposits from eolian removal of fines (Waters 1992:205-206), colluvial movement of gravels, sediment-supported clast retention at surface (i.e., desert pavement, McFadden et al. 1987), or a combination of these processes. The surface distribution of gravels was dissimilar to the clast content of the A horizon soils. Below the A3 horizon was a gravel deposit $(\mathrm{Ck})$ that was a poorly sorted silty clay that was clast supported. This horizon was $20-50$ $\mathrm{cm}$ thick. The maximum size of the gravels in the $\mathrm{Ck}$ horizon was approximately $10 \mathrm{~cm}$. There appeared to be a greater number of larger gravels situated at the base of this deposit indicating a fining-upward sequence. The lower boundary was an abrupt wavy-irregular erosional unconformity. The 2Ck horizon underneath the $\mathrm{Ck}$ was fine, well-sorted silt clay that contained few clasts that were $5 \mathrm{~cm}$ or less in maximum dimension. This finer sediment was maximally $60 \mathrm{~cm}$ thick. It was much thinner $(<10 \mathrm{~cm})$ at the northern end of the trench where the underlying gravels of the $3 \mathrm{Ck}$ horizon were situated at a slightly higher elevation than the rest of the $3 \mathrm{Ck}$ deposit. Underneath the $2 \mathrm{Ck}$ was a robust gravel deposit that was approximately $20-50 \mathrm{~cm}$ thick. This 
clast-supported deposit contained gravels as large as $15 \mathrm{~cm}$ in maximum size. There was an increased presence of clays within all of these $\mathrm{Ck}$ horizons. The lower boundary of $3 \mathrm{Ck}$ was an erosional unconformity with a series of much older $\mathrm{B}$ horizon soils. The greater age of these soils was indicated by much greater pedogenic morphology than the overlying $\mathrm{A}$ and $\mathrm{C}$ horizons. The Btkn1-Btkn3 soils exhibited strong, coarse prismatic structure, thick continuous clay films, salt accumulations, and significant rubification. Filaments up to $6 \mathrm{~mm}$ thick and crystals of unspecified salts were readily apparent in these horizons, especially in Btkn2. No samples were collected from these profiles for analyses but these horizons have been described as containing sodium, gypsum, and other soluble salts (Sanders and Gabriel 1985:73, 86).

\section{Backhoe Trench 2}

Backhoe Trench 2 was located within the densest distribution of surface artifacts to determine whether there was any subsurface component to the deposit and address site formation. Surface gravels at this location were much denser than those in the area where BHT 1 was excavated. This area was at the margin of a slight rise and there was a gentle slope to the area investigated. The upslope area west of BHT 2 had been significantly impacted by mechanical blading, borrow pit excavation, and mounding of sediments so that it was difficult to determine the original geomorphic relationship between these areas of the site. Although there were abundant flakes, cores, and early stage bifaces on the surface in this location, no archaeological materials or charcoal were identified in either wall of this trench.

BHT 2 was $11.07 \mathrm{~m}$ long and excavated to a maximum depth of $1.7 \mathrm{~m}$ below the ground surface. This trench was oriented $98^{\circ}-278^{\circ}$ from magnetic north so that it would sample the densest distribution of surface artifacts on the site. The soils in BHT 2 were similar to those seen in BHT 1, but some differences were apparent. The southern wall of this trench was profiled (Figure 4-8) and described (Table 4-4). The A horizons were much thinner in this trench than those recorded for BHT 1. At the western (upslope) end of the trench the A1-A2 soils were maximally $20 \mathrm{~cm}$ thick. The A2 was not identified in the eastern $9 \mathrm{~m}$ of this profile and the A1 was less than $5 \mathrm{~cm}$ thick. Unlike the A horizons in BHT 1 , clasts $<5 \mathrm{~cm}$ were common in both $\mathrm{A} 1$ and $\mathrm{A} 2$. This was a very recent epipedon developed on the gravel deposits of Ck1 and Ck2. Ck1 was distinguished only in the western $1.9 \mathrm{~m}$ of the profile. It did not appear to be a separate depositional episode from $\mathrm{Ck} 2$, but showed a visibly distinct whitening from greater $\mathrm{CaCO}_{3}$ accumulation than the gravels

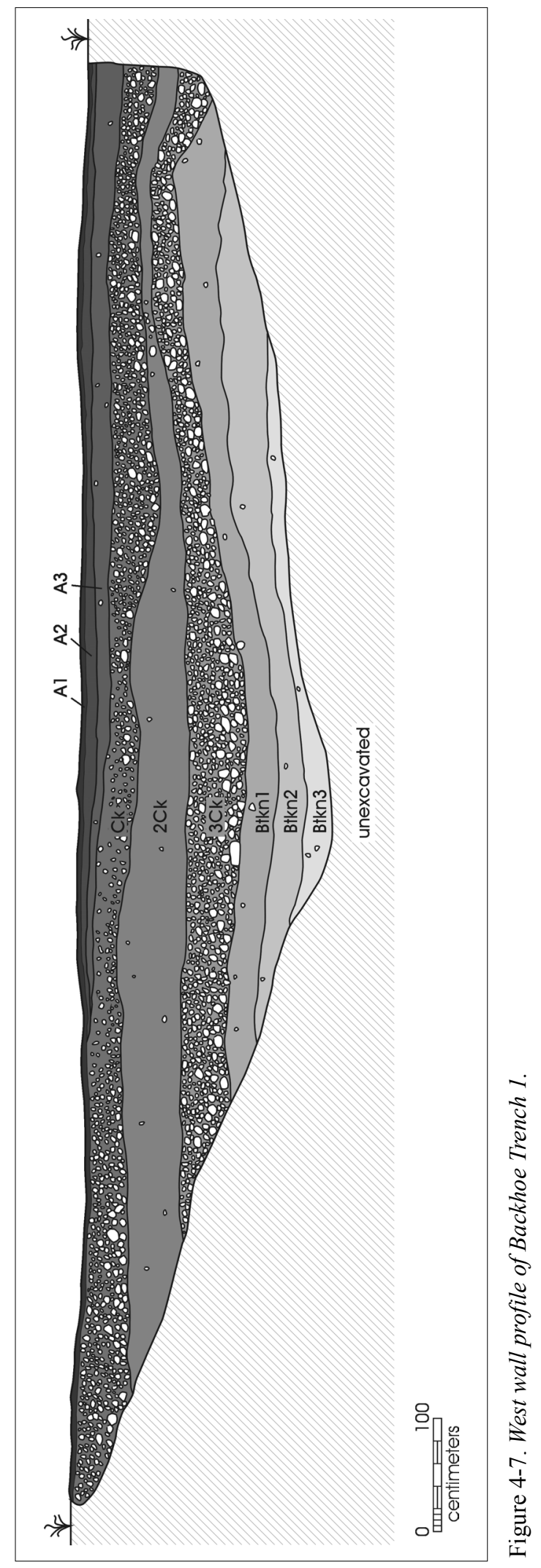




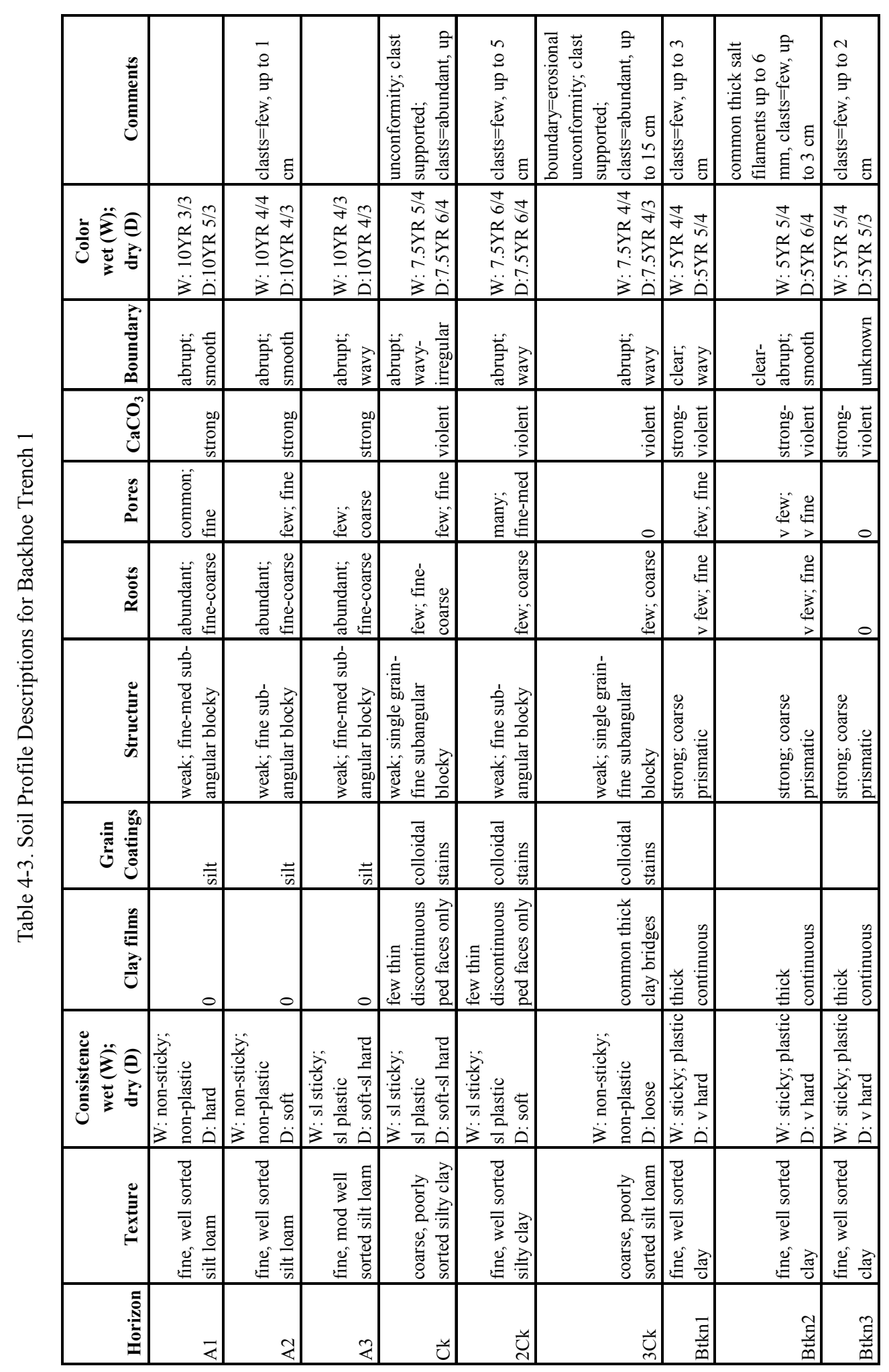


below. The $\mathrm{Ck}$ gravels were thickest in the western $2 \mathrm{~m}$ of this profile (maximally $60 \mathrm{~cm}$ ) and thinned dramatically $(\sim 10-25 \mathrm{~cm})$ between approximately $3-8 \mathrm{~m}$ east of the western end of BHT 2. Gravel density was much lower in this thinner portion of the Ck2. The gravel deposit was thicker $(\sim 30-40 \mathrm{~cm})$ and denser between approximately 8.3 and $11.07 \mathrm{~m}$ east of the western end of the trench. The proximity of the ground surface to the upper boundary of the $\mathrm{Ck} 1$ and $\mathrm{Ck} 2$ horizons indicates that the surface gravels were probably derived from these high-energy sediments. The lower boundary of $\mathrm{Ck} 2$ was an erosional unconformity and was deepest at the western end of the trench. Underneath this gravel deposit was a $20-35 \mathrm{~cm}$ thick silty clay deposit that contained almost no clasts. This Btk soil showed strong structure with coarse prismatic peds. The lower boundary was very sharp and appeared to represent an erosional unconformity. The $2 \mathrm{Ck}$ was a well-sorted sandy clay loam and was the only horizon examined with a significant amount of sand. This weakly developed soil was $12-30 \mathrm{~cm}$ thick and was conformable with the underlying horizons. Underneath $3 \mathrm{Ck}$ were three older Btkn soils that were essentially identical to those described in BHT 1.

\section{Discussion}

Geoarchaeological investigations did not identify any buried component to the surface archaeological site encountered during this investigation. The lowest horizons exposed in both trenches (Btkn1-Btkn3) were a much older remnant soil that were genetically unrelated to sedimentary and pedogenic events in the upper portions of the profiles. All of the Btkn soils showed higher pedogenic clay content, stronger structure and rubification that indicate much greater age than the overlying deposits. There were slight differences in the stratigraphy above this older soil in each trench, however, both profiles indicated a dominance of alluvial depositional events. BHT 1 had erosion of the upper Btkn soil and deposition of high-energy gravels (3Ck) that showed a fining-upward sequence. A fine alluvial or eolian silty clay sediment (2Ck) covered those gravels indicating either surface stability or channel meander. An unknown amount of the upper portion of $2 \mathrm{Ck}$ was eroded and covered by the uppermost gravel (Ck) deposit. The weak development of 2Ck suggests the high-energy flood events responsible for $\mathrm{Ck}$ and $3 \mathrm{Ck}$ were not widely separated in time. Above the uppermost high-energy gravels in BHT 1, the A horizons were fine silt loams with weak structure that appeared to be relatively recent. Relatively few archaeological artifacts were found in the vicinity of BHT 1.

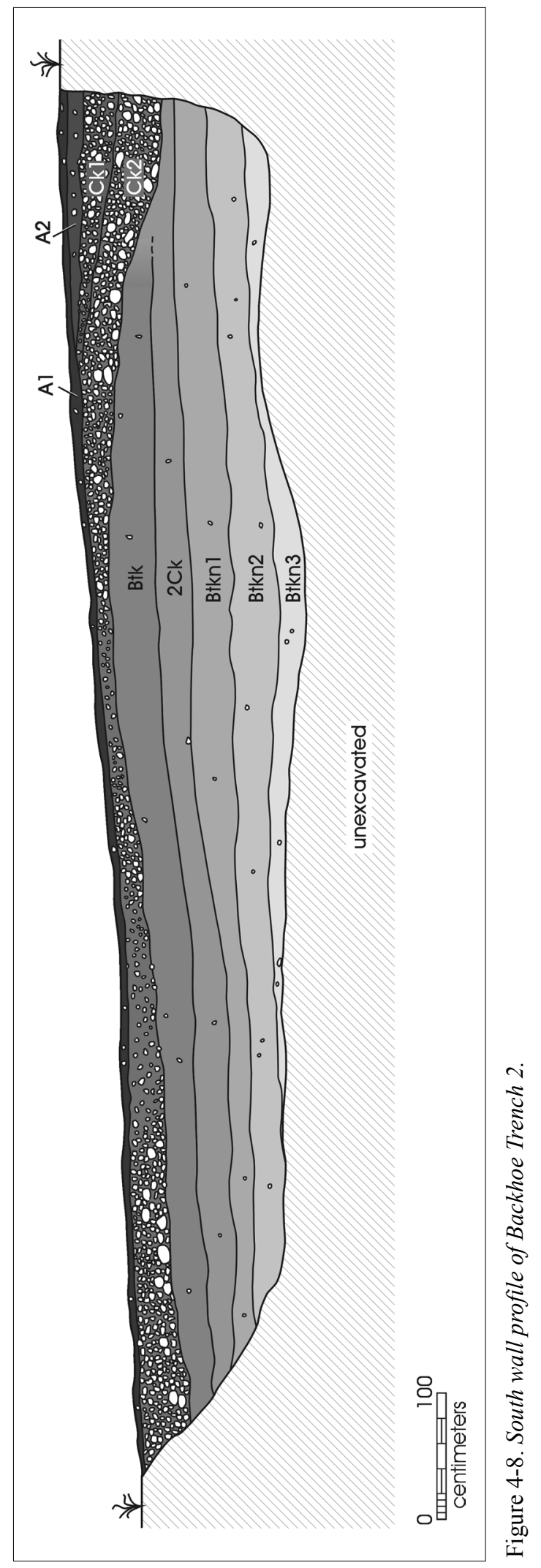




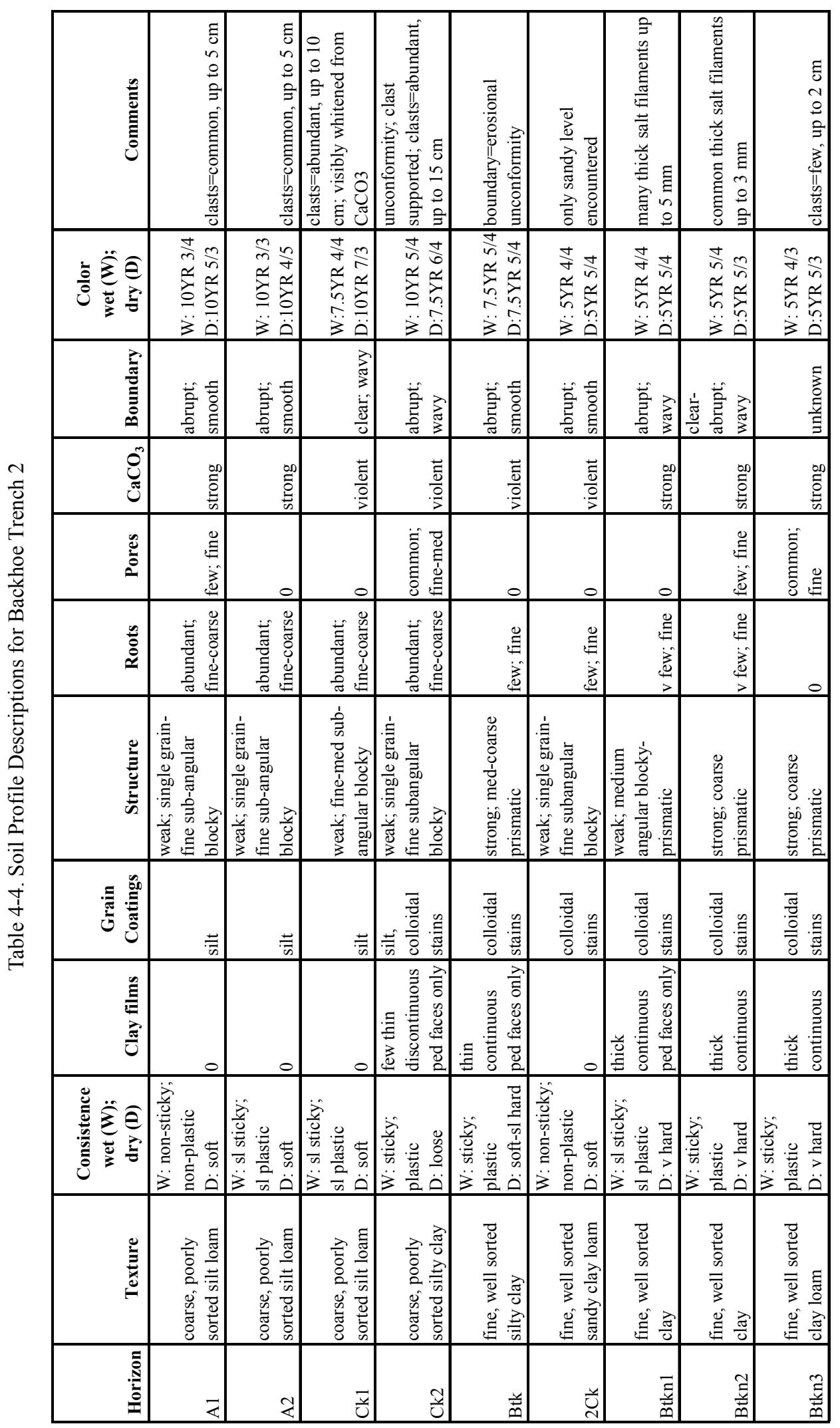


In BHT 2 the 2Ck deposit overlying Btkn1 was a well-sorted alluvial sandy loam with almost massive structure. The upper boundary of this sediment (2Ck) with Btk appeared to be an erosional unconformity. The Btk horizon showed strong structural development apparently indicating a period of stability and pedogenesis. The upper boundary of Btk was eroded and there was no evidence of the former A horizons. The Btk was surmounted by the gravel deposits Ck1 and $\mathrm{Ck} 2$ that were equivalent to at least the uppermost gravel unit in BHT $1(\mathrm{Ck})$. There was an apparent fining upward within both of the gravel deposits indicating an alluvial origin. The A horizon soils above these gravels in BHT 2 were much thinner and contained a large number of small clasts. They were more weakly developed than the A horizons in BHT 1 and appeared to be more recent. This may be due to mechanical removal of some of the solum, recurrent natural erosion at this hill slope margin setting, or colluvial overthickening of the A horizons in the more level BHT 1 setting.

The prehistoric lithic artifacts show no evidence of alluvial or colluvial abrasion and only minimal patination was observed on a few pieces. This suggests that they are not the product of significant high-energy redeposition. Although the surface gravels may have been formed by colluvial or eolian processes, the fresh, undamaged edges of the lithics indicate that events concentrating the gravels probably occurred prior to deposition of the archaeological materials. The depth of the gravel deposits in BHTs $1(\mathrm{Ck})$ and 2 (Ck1 and Ck2) below the surface appear correlated with surface lithic density. More gravels and artifacts are present in the vicinity of BHT 2 where the gravels were $<5$ $\mathrm{cm}$ below surface than in BHT 1 where the uppermost $\mathrm{Ck}$ gravels were approximately $25 \mathrm{~cm}$ below the modern ground surface. This could suggest that artifact visibility is associated with more stable land surfaces. Unfortunately, the situation is complicated by a history of mechanical surface disturbance to remove shrub vegetation for improved cattle grazing. Although there is likely an undetermined amount of spatial disturbance from this blading across most of the project area, few of the lithics that were unsystematically examined showed damage from this activity. It is unknown whether areas adjacent to the parcel investigated in this survey may contain more intact surfaces that could help address site formational dynamics in this area. 
Phase I Survey of a Habitat for Humanity Tract in Laredo

\section{Chapter 5: Summary and Recommendations}

On December 7, 2004, the Center for Archaeological Research (CAR) conducted a Phase I intensive pedestrian archaeological survey of a 10 -acre portion of Tract 4 in the Las Blancas Subdivision located near Laredo in Webb County, Texas, for Habitat for Humanity of Laredo. The proposed development consists of the construction of lowincome housing within this parcel.

Twenty shovel tests and two backhoe trenches were excavated within the parcel. The survey found that the western portion of the project area has been heavily disturbed by previous land clearing and the mining of gravels and/or caliche. All shovel tests excavated in this part of the property (STs 1-8) were negative for cultural materials and reflected heavy disturbance of the area. The surface across the remainder of the project area was covered by a low density of lithic cultural material including early reduction stage bifaces, cores and core fragments, and debitage. A concentration of these materials measuring approximately $65 \times 45$ meters was noted in the central portion of the parcel. Twelve shovel tests and a backhoe trench were excavated within the portion of the parcel containing surface artifacts. While six shovel tests contained cultural materials, in only one case (ST 10) did the materials come from a buried context ( $0-30 \mathrm{cmbs})$. Neither of the two backhoe trenches excavated on site revealed buried cultural deposits. No features were identified on surface or in a buried context across the site.

Based on the presence of a low to moderate density of lithic artifacts on the surface of the property, 41WB633 was defined as a lithic procurement area. The site covers 6.36 acres of the total project area, roughly $3 / 5$ of the tract. The shovel tests and backhoe trenches excavated on site suggest that the materials occur solely on surface. The subsurface materials in ST 10 may have worked their way down the profile through post-depositional agents such as bioturbation or other activities such as land clearing and gravel mining that heavily impacted the western portion of the 10-acre parcel. Surface cultural materials extend to the boundaries of the parcel indicating that the actual limits of the site are beyond the project area. No work was done outside of the project area itself; however, site 41WB442, a prehistoric camp site, was documented in 1997 at the southern edge of Tract 4. It is possible that $41 \mathrm{WB} 633$ may have served as an intermittently used lithic procurement area for the inhabitants of 41WB442. However, this is simply conjecture, since at this time we have no evidence linking the two sites in this manner.

The geoarchaeological and artifact distributional data from this survey represents a very small sample with uncertain taphonomic history that cannot be readily extrapolated to make secure technological or site formation inferences. However, at a very coarse scale, it appears that patterning in archaeological visibility likely does provide some parameters about prehistoric behaviors at this site. The archaeological deposits are primarily surficial, although they may extend to the top of the uppermost gravel deposit. In addition to recent mechanical disturbances, this site is likely to have experienced cycles of natural exposure and reburial. The disturbances of surface sites are readily appreciated but they also offer the advantage of continuous, large-scale exposure of some portion of the archaeological record. Although finegrained site structural patterning probably cannot be addressed at this location, the influence of landform and substrate can be examined. The co-association of a higher density of surface gravels and artifacts may suggest that reduction of stone occurred at a higher frequency in locations where knappable raw materials were available prehistorically. The presence of many large flakes, cores, and minimally reduced bifacially tested cobbles or cores is consistent with knapping seen at other locations with abundant and ubiquitous raw material availability (Greaves 2001:302-303; Vierra 1998:144-146). Because cherts and quartzites are readily available, this area may represent a range of behaviors with lithic traces. Some lithic provisioning may have occurred but the ubiquity of raw material also can result in a range of expedient and more planned tool production and use events that are not preserved at sites with more limited access to stone.

\section{Recommendations}

The western portion of the project area has been heavily impacted by land clearing and gravel/caliche mining. No intact cultural deposits were documented on this portion of the property. The eastern portion of the parcel contains low to moderate densities of lithic artifacts with a concentration roughly in the center of the site. However, although one shovel test did yield subsurface materials, it is likely that these materials are not in their original depositional context. 
Surface-manifested lithic procurement sites lacking temporally diagnostic artifacts and possibly containing palimpsests of repeated uses of the landform separated by thousands of years have little research potential within the current chronologically-anchored archaeological paradigm. It is difficult to differentiate the multiple contributing behaviors to such surface assemblages and to assign such sites temporal affiliation. While such lithic procurement sites can provide information on use of landforms for raw material procurement within raw-material-rich or raw-material-poor areas, regardless of chronological control, until and unless theoretical frameworks are developed for atemporal research approaches to these sites, their research potential cannot be demonstrated. Within this context, and given the reasons mentioned here, CAR recommends that site $41 \mathrm{WB} 633$ has little research potential for addressing chronologically framed research questions. Although a low to moderate density of cultural materials does occur on site, these artifacts cannot be brought together into the current models for understanding human behavior within the region and the state. Therefore, we recommend that site 41WB633 does not warrant official designation as a State Archeological Landmark and does not merit nomination to the National Register of Historic Places. Finally, even though the proposed development of the Habitat for Humanity housing subdivision will result in the destruction of the site, no additional work is recommended on site prior to the inception of the planned construction activities. 


\section{References Cited}

Birkeland, P. W.

1984 Soils and Geomorphology. Oxford University Press, New York.

Black, S. L.

1989 South Texas Plain. In From the Gulf Coast to the Rio Grande: Human Adaptation in the Central, South, and Lower Pecos Texas, by T. R. Hester, S. L. Black, D. G. Steele, B. W. Olive, A. A. Fox, K. J. Reinhard, and L. C. Bement, pp. 39-62. Research Series No. 33. Arkansas Archaeological Survey, Fayetteville.

Blair, W. F.

1950 The Biotic Provinces of Texas. Texas Journal of Science 2(1):93-117.

Bousman, C. B.

1998 Paleoenvironmental Change in Central Texas: The Palynological Evidence. Plains Anthropologist (43)164:201219.

Brown, D. E.

1994 Chihuahuan Desertscrub. In Biotic Communities: Southwestern United States and Northwestern Mexico, edited by D. E. Brown, pp. 169-179. University of Utah Press, Salt Lake City.

Greaves, R. D.

2001 Archaeological Survey and Testing Along the Rio Grande Terraces Near Eagle Pass and El Indio, Maverick County, Texas. Report of Investigations No. 4. Wendy Lopez \& Associates, Dallas.

Groat, G. G.

1976 Geologic Atlas of Texas: Laredo Sheet. Bureau of Economic Geology. The University of Texas at Austin.

Hester, T. R.

1995 The Prehistory of South Texas. Bulletin of the Texas Archeological Society 66:427-459.

Holloway, R. G.

1986 Macrobotanical Analysis of Phase II Materials from the Choke Canyon Reservoir Area, Texas. In Prehistoric Sites at Choke Canyon Reservoir, Southern Texas: Results of Phase II Archaeological Investigations, by G. D. Hall, T. R. Hester, and S. L. Black, pp. 437-451. Choke Canyon Series, No. 10. Center for Archaeological Research, The University of Texas at San Antonio.

McFadden, L. D., S. G. Wells, and M. J. Jercinovich

1987 Influences of Eolian and Pedogenic Processes on the Origin and Evolution of Desert Pavements. Geology 15:504508.

Nordt, L. C.

1998 Chapter 7: Geoarcheology of the Rio Grande and Elm Creek in the Vicinity of Site 41MV120. In 41MV120: A Stratified Late Archaic Site in Maverick County, Texas, by B. J. Vierra, pp. 43-77. Archaeological Survey Report, No. 251, Center for Archaeological Research, The University of Texas at San Antonio; Archeology Studies Program, Report No. 7, Environmental Affairs Division, Texas Department of Transportation, Austin. 
Sanders, R. R., and W. J. Gabriel

1985 Soil Survey of Webb County, Texas. U.S. Department of Agriculture, Soil Conservation Service, in cooperation with the Texas Agricultural Experiment Station.

Soil Survey Staff

1993 Soil Survey Manual. U.S. Department of Agriculture Handbook No. 18. U.S. Department of Agriculture. U.S. Government Printing Office, Washington, D.C.

Texas Historical Commission (THC)

2004 Texas Archeological Sites Atlas. <http://www.pedernales.thc.state.tx.us/>.

Vierra, B. J.

1998 41MV120: A Stratified Late Archaic Site in Maverick County, Texas. Archaeological Survey Report, No. 251, Center for Archaeological Research, The University of Texas at San Antonio; Archeology Studies Program, Report No. 7, Environmental Affairs Division, Texas Department of Transportation, Austin.

Waters, M. R.

1992 Principles of Geoarchaeology: A North American Perspective. University of Arizona Press, Tucson. 